in the discipline. Attendees spend one hour and forty-five minutes (the same amount of time they would spend in a panel session) circulating among booths where presenters display key graphics and text relevant to their research project. The presenters and attendees are encouraged to discuss the research findings and plan future projects.

The RBSI students spent a total of three and a half days at the Annual Meeting with Maurice Woodard, APSA Director of Minority Affairs, serving as their host. In addition to presenting their posters, the students attended universitysponsored receptions where they were invited to discuss plans for graduate study one-on-one with faculty and other students. They were encouraged to meet other African American scholars at a special reception sponsored by the Committee on the Status of Blacks in the Profession, to visit the book exhibit, and to attend numerous academic panels. The students also attended the Award Winning Breakfast-a session of small group discussions among students and distinguished senior political scientists.

\section{Hallet Award Donated to Centennial Campaign in Gosnell's Name}

After naming the late Harold Gosnell the recipient of its 1997 George Hallet Award, the executive committee of the Organized Section on Representation and Electoral Systems announced that it will be donating the monetary portion of the award to APSA's Centennial Campaign. Funds collected during the five-year Centennial Campaign, which will be launched officially during the 1998 Annual Meeting in Boston, will be used to develop and support new and expanded teaching, training, and research opportunities for political scientists. To receive more information about the Centennial Campaign and its mission and goals, please write to Centennial Campaign, 1527 New Hampshire Avenue, NW, Washington, DC 20036, or send email to future@apsanet.org.

\section{New APSA Officers and Council Elected}

At the close of the 93rd Annual Meeting in Washington, the slate of officers and council members put forward by the APSA Nominating Committee was unanimously accepted. The 1997-98 officers are:

President: M. Kent Jennings, University of California, Santa Barbara

President-Elect: Matthew Holden, University of Virginia

Vice Presidents: Rodolfo O. De La Garza, University of Texas at Austin; Jennifer Hochschild, Princeton University; Robert D. Putnam, Harvard University

Secretary: Toni-Michelle Travis, George Mason University

Treasurer: Timothy Cook, Williams College

The newly elected members of the Council, APSA's governing body, are:

Jane Bayes, California State University, Northridge

Gary W. Cox, University of California, San Diego

Charles D. Hadley, University of New Orleans

Kristen R. Monroe, University of California, Irvine

Pippa Norris, Harvard University

Beth A. Simmons, University of California, Berkeley

Joan C. Tronto, Hunter College, CUNY

Michael Wallerstein, Northwestern University

Council members will serve through 1999.

\section{Finifter Renewed, Other APSA Council Actions}

The Council of the Association met on August 27, at the Omni Shoreham Hotel as part of the 1997 Annual Meeting in Washington, D.C. Council members took the following important actions:

- Approved the renewal of a second three-year term for American Political Science Review Editor Ada Finifter.

- Recommended APSA endorsement of the Woodrow Wilson
Center in response to Martha $\mathrm{Ku}$ mar's report that a House subcommittee recommended appropriation reductions in the

Smithsonian's Woodrow Wilson Center budget that would amount to a virtual shutdown of the Center.

- Recommended that steps be taken to insure APSA representation on appropriate National Archives and Records Administration and other governmental boards.

- Allocated to the Committee on International Programs $\$ 5,000$ to start an Initiative and Exchanges Fund and another $\$ 5,000$ to continue institutional membership/ journal donations to foreign institutions; the Council also endorsed general guidelines for journal donations.

- Approved a joint Exchange Service between APSA and the European Consortium for Political Research as a pilot project and endorsed a web-based approach to it. The exchange project will facilitate temporary placements of European political scientists in the U.S. and vice versa.

- Approved the proposed budget for FY $97-98$, which projects a $6 \%$ increase in both income and expenditures

- Adopted changes in the wording of the Association's anti-discrimination and affirmative action statements, proposed jointly by the Ethics Committee and the Committee on the Status of Lesbians

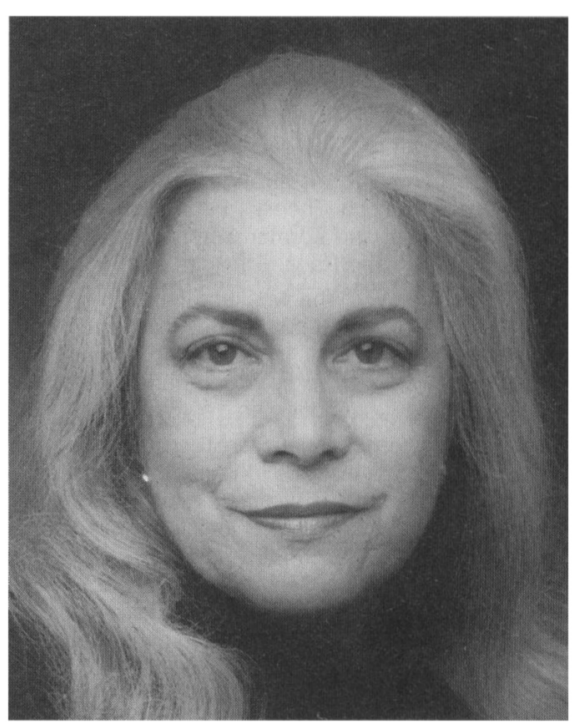

Ada Finifter 